\title{
Uji Adsorpsi Bentonit Teraktivasi KOH Terhadap Logam Cu(II)
}

\author{
Mega Roikhanah Fauziyati ${ }^{1}$ \\ 1Jurusan Kimia, UIN Walisongo Semarang \\ *E-mail: megaroikhanahfauziyati05@gmail.com
}

\begin{abstract}
Abstrak
Peningkatan perkembangan industri setiap tahun menyebabkan limbah cair yang dihasilkan semakin meningkat. Limbah yang tidak mengalami pengolahan menyebabkan pencemaran lingkungan. Salah satu upaya untuk mengurangi kadar ion logam dalam limbah yaitu meminimalisir kandungan ion logam berat menggunakan metode adsorpsi. Penelitian ini bertujuan mempelajari pengaruh proses aktivasi pada bentonit dengan menggunakan $\mathrm{KOH}$ dan mengaplikasikannya sebagai adsorben ion logam $\mathrm{Cu}(\mathrm{II})$. Parameter yang digunakan pada penelitian ini adalah variasi konsentrasi aktivator $\mathrm{KOH}$, waktu optimum dan $\mathrm{pH}$. Selain itu studi kinetika adsorpsi juga dipelajari dalam penelitian ini. Hasil penelitian menunjukkan adsorben terbaik adalah bentonit teraktivasi KOH 6M. Karakteristik bentonit ditandai dengan munculnya gugus spesifik Si-O dan Si-O-Si pada panjang gelombang 1009,31 $\mathrm{cm}^{-1}$ dan $466,71 \mathrm{~cm}^{-1}$, munculnya difaktogram khas montmorillonit pada intensitas $2 \theta=20,880^{\circ}$ (d=4,508 $\AA$ ), luas permukaan spesifik 87,2001 $\mathrm{m}^{2} / \mathrm{g}$ dengan kapasitas adsorpsi 50,013 mg/g. Kondisi optimum waktu kontak adalah 120 menit pada konsentrasi awal ion logam $\mathrm{Cu(II)} 1000$ ppm $50 \mathrm{ml}$. Adsorpsi ini mengikuti model kinetika pseudo orde dua dengan konstanta laju adsorpsi ion logam $\mathrm{Cu}(\mathrm{II})$ sebesar $9,08 \times 10^{-4}$ g.mg-1.
\end{abstract}

Kata kunci: Bentonit teraktivasi; KOH; Adsorpsi; Ion logam $\mathrm{Cu}(\mathrm{II})$

\section{Pendahuluan}

Tahun 2050 di seluruh dunia akan terjadi peningkatan permintaan logam pada industri logam sebanyak lima kali dari saat ini. Permintaan logam seperti $\mathrm{Au}, \mathrm{Ag}, \mathrm{Cu}, \mathrm{Ni}$, $\mathrm{Sn}, \mathrm{Zn}, \mathrm{Pb}$ dan $\mathrm{Sb}$ akan lebih besar daripada Fe dan Pt (Halada et al., 2008). Jika sesuai prediksi, maka proses industri membutuhkan jumlah logam yang sangat banyak sebagai bahan baku agar produksi dapat terus berjalan. Artinya limbah yang dihasilkan juga meningkat. Limbah industri yang tidak mengalami pengolahan akan menyebabkan pencemaran lingkungan, sehingga menyebabkan munculnya perumusan peraturan pemerintah melalui Kep-51/MENLH/10/ 1995 mengenai kualitas air limbah yang dikeluarkan oleh industri, dimana baku mutu limbah cair industri golongan 1 kandungan logam tembaga yaitu kurang dari $2 \mathrm{mg} / \mathrm{L}$. Sumber utama penyumbang logam berat $\mathrm{Cu}$ adalah industri pelapisan logam (plating), pencampuran logam (alloy), baja, pewarna, kabel listrik, insektisida, jaringan pipa, dan cat (Venkatiswaran et al., 2007).

Pengolahan industri cair dari industri pelapisan logam sampai saat ini belum berhasil dengan baik. Salah satu penyebabnya karena metode pengolahan yang banyak digunakan adalah metode lumpur aktif. Metode lumpur aktif adalah proses pengolahan air limbah dengan biakan mikroba tersuspensi (Biyatmoko dkk, 2012). Metode ini mempunyai kekurangan yaitu sulit diaplikasikan dibandingkan dengan metode pengolahan yang lain. Beberapa metode perlakuan untuk mengolah ion 
logam berat dalam limbah industri telah dilaporkan dalam beberapa pustaka (Gupta \& Bhattacharayya, 2008). Metode tersebut adalah netralisasi, presipitasi, biosorpsi, adsorpsi dan pertukaran ion. Metode adsorpsi terbukti menjadi metode yang efektif untuk meminimalisir logam berat dalam air limbah industri, terutama untuk kadar logam berat yang rendah. Kelebihan metode ini adalah tergolong metode yang efisien, pengoperasiannya simpel dengan biaya operasional yang murah dan ramah lingkungan serta hasil yang diperoleh optimal. Material dasar yang dapat di jadikan sebagai adsorben dalam metode adsorpsi antara lain karbon aktif (Meilita, 2003), zeolit, abu terbang batubara (Jiang et al., 2018), sargassum, kaolin (Gupta \& Bhatthacarayya, 2008), bentonit (Eren dan Afsin, 2007).

Penyusun utama bentonit adalah silika dan alumina, kandungan lainnya yaitu $\mathrm{Fe}, \mathrm{Mg}, \mathrm{Ca}, \mathrm{Na}, \mathrm{Ti}$, dan K. Kandungan silika yang ada dalam bentonit dapat dimanfaatkan sebagai bahan penyerap karena silika mempunyai fungsi sebagai penukar ion yang baik (Hardyanti dkk, 2017). Oleh sebab itu, bentonit cocok dimanfaatkan sebagai adsorben alternatif, karena biaya yang dikeluarkan murah dan bentonit terdapat melimpah di alam (Roland, 2015). Bentonit yang tidak dimodifikasi memberikan hasil yang kurang maksimal sebagai aplikasi adsorben. Kelemahan tersebut dapat diatasi melalui proses aktivasi, zat kimia yang dapat digunakan dalam aktivasi adalah asam $\left(\mathrm{H}_{3} \mathrm{PO}_{4}, \mathrm{H}_{2} \mathrm{SO}_{4}, \mathrm{HCl}\right)$, zinc klorida $\left(\mathrm{ZnCl}_{2}\right)$, alkali hidroksida $(\mathrm{KOH}, \mathrm{NaOH})$ dan karbonat $\left(\mathrm{K}_{2} \mathrm{CO}_{3}, \mathrm{Na}_{2} \mathrm{CO}_{3}\right)$. Aktivasi berfungsi untuk membersihkan pengotor dari permukaan adsorben dan mengubah gugus aktif pada adsorben sehingga dapat meningkatkan selektifitas pada adsorben. Masing-masing jenis aktivator akan memberikan pengaruh yang berbeda-beda terhadap luas permukaan maupun volume pori-pori adsorben yang dihasilkan.

Oleh karena itu, penelitian ini bertujuan untuk mengkaji hasil karakteristik adsorben bentonit teraktivasi $\mathrm{KOH}$ menggunakan FTIR, XRD, SAA, dan menilai kemampuannya dalam menyerap ion $\mathrm{Cu}^{2+}$ menggunakan instrumen AAS.

\section{Metode Penelitian}

\section{Alat dan Bahan}

Bahan yang digunakan adalah bentonit dari toko kimia indrasari, $\mathrm{KOH} 6 \mathrm{M}$ dan $12 \mathrm{M}$, aquadest, $\mathrm{CuSO}_{4} \cdot 5 \mathrm{H}_{2} \mathrm{O}$. Peralatan yang digunakan dalam penelitian ini antara lain adalah desikator, oven merk Menmert, kertas saring whatman No.42, furnace, ayakan, seperangkat alat gelas, seperangkat alat reflux, neraca analitik, pH meter, magnetic stirrer, Gas Sorption Analyzer (GSA), $X$-ray Diffraction (XRD), Fourier Transform Infrared Spectroscopy (FT-IR) dan Atomic Absorbsion Spectroscopy (AAS).

\section{Aktivasi Adsorben}

Bentonit dalam keadaan kering direfluks dalam larutan $\mathrm{KOH}$ dengan variasi konsentrasi KOH $6 \mathrm{M}$ dan 12 M selama 6 jam, perbandingan rasio berat bentonit : $\mathrm{KOH}=1$ :4. Sampel yang dihasilkan disaring dalam keadaan panas menggunakan kertas saring whatman No.42, kemudian dinetralkan menggunakan larutan air suling hingga larutan menjadi netral $(\mathrm{pH}=7)$. Sampel dikeringkan dalam oven pada suhu $100^{\circ} \mathrm{C}$ selama 3 jam (sun et al., 2018, Jinxiao Li, 2017, Ramya et al, 2017, Ariyani, 2017).

\section{Proses Kalsinasi}

Bentonit teraktivasi dalam keadaan kering dikalsinasi menggunakan furnace pada suhu $500{ }^{\circ} \mathrm{C}$ selama 1 jam. Kemudian didiamkan dalam furnace hingga panasnya turun dan dipindahkan ke desikator sampai dingin, lalu diayak menggunakan ayakan berukuran 60 mesh (Simparmin dkk, 2018).

\section{Proses Uji Adsorpsi}

Proses uji adsorpsi dilakukan menggunakan metode batch. Adsorben diambil sebanyak 1 gram, kemudian ditambahkan $50 \mathrm{~mL}$ larutan ion logam $\mathrm{Cu}(\mathrm{II}) 1000$ ppm diaduk menggunakan magnetic stirrer dengan suhu $25^{\circ} \mathrm{C} \pm 2^{\circ} \mathrm{C}$ selama 60 menit. Selanjutnya disaring menggunakan penyaring bunchner untuk memisahkan filtrat dan endapannya. 
Filtratnya diambil dan dianalisis daya adsorpsinya menggunakan AAS kemudian dikarakterisasi (Al-Shahrani, 2013).

\section{Penentuan Waktu Optimum}

Penentuan waktu optimum interaksi antara adsorben dan adsorbat menggunakan adsorben terbaik dari ketiga jenis adsorben. Uji adsorbsi ini menggunakan metode batch. Dimana gelas beker diisi adsorben terbaik sebanyak 1 gram, kemudian ditambahkan 50 ml larutan ion logam Cu(II) 1000 ppm diaduk menggunakan magnetic stirrer dengan kecepatan 150 rpm pada suhu $25^{\circ} \mathrm{C} \pm 2{ }^{\circ} \mathrm{C}$ dan dilakukan variasi waktu interaksi yaitu 15 menit, 30 menit, 45 menit, 60 menit, 75 menit, 90 menit, 105 menit, 120 menit, 135 menit, 150 menit, 165 menit dan 180 menit. Selanjutnya disaring menggunakan penyaring bunchner untuk memisahkan larutan dan endapannya. larutannya diambil dan dianalisis menggunakan AAS, FTIR, XRD, SAA (Kanogwan et al., 2018, Al-Shahrani, 2013).

\section{Penentuan pH Optimum}

Sebanyak 1 gram adsorben terbaik dimasukkan dalam Erlenmeyer dan ditambahkan $50 \mathrm{ml}$ larutan $\mathrm{CuSO}_{4} \cdot 5 \mathrm{H}_{2} \mathrm{O}$ dengan konsentrasi 1000 ppm. pH larutan divariasi $\quad 3,4,5,6,7,8,9,10,11$ dengan menambahkan larutan $\mathrm{HCl}$ dan $\mathrm{NaOH}$. Kemudian larutan diaduk menggunakan magnetic strirer selama 120 menit dengan keepatan $150 \mathrm{rpm}$ dalam suhu ruang. Larutan disaring dan filtratnya diambil, kemudian diukur absorbansinya dengan menggunakan AAS.

\section{Hasil Penelitian dan Pembahasan}

\section{Aktivasi Adsorben}

Aktivasi terhadap bentonit merupakan proses yang bertujuan untuk meningkatkan perfomance permukaan dan kandungan bentonit. Aktivasi kimia dalam penelitian ini dilakukan dengan metode refluks dimana aktivator yang digunakan adalah larutan $\mathrm{KOH}$ dengan variasi konsentrasi $6 \mathrm{M}$ dan $12 \mathrm{M}$. Perlakuan awal yang dilakukan adalah mencampurkan bentonit dan larutan aktivator dengan perbandingan 1:4 selama 6 jam dengan kecepatan $150 \mathrm{rpm}$, hal ini bertujuan untuk menghilangkan pengotor yang ada pada kisi struktur bentonit, sehingga struktur bentonit menjadi aktif dan pori-pori bentonit menjadi lebih terbuka. Semakin banyak pori yang terbuka pada permukaan bentonit maka proses adsorpsi akan berlangsung baik dengan banyaknya adsorbat yang terserap pada pori bentonit.

\section{Karakterisasi Bentonit}

Adsorben yang dihasilkan dalam penelitian ini ada tiga yaitu bentonit tanpa aktivasi, bentonit teraktivasi $\mathrm{KOH} 6 \mathrm{M}$ dan bentonit teraktivasi $12 \mathrm{M}$. Ketiga adsorben ini kemudian dikarakterisasi menggunakan $X$-ray Diffraction, Fourier Transform Infrared Spectroscopy dan Gas Sorption Analyzer.

\section{Hasil Analisa FT-IR Pada Bentonit}

Analisa bentonit menggunakan FT-IR pada penelitian ini bertujuan untuk mengetahui gugus fungsional apa saja yang ada pada bentonit dan apakah terjadi perubahan gugus fungsional utama pada BTA dan BTK. Hasil dari analisa bentonit berupa puncak pita serapan pada spektra FT-IR. Kandungan yang menjadi ciri khas bahwa senyawa tersebut merupakan bentonit adalah montmorillonit, dimana montmorillonit mempunyai pita-pita serapan yang khas yaitu muncul pada bilangan gelombang $3629 \mathrm{~cm}^{-1}, 3425 \mathrm{~cm}^{-1}$, $1654 \mathrm{~cm}^{-1}, 3284 \mathrm{~cm}^{-1}, 1031 \mathrm{~cm}^{-1}, 696 \mathrm{~cm}^{-1}$, $634 \mathrm{~cm}^{-1}, 912 \mathrm{~cm}^{-1}, 545 \mathrm{~cm}^{-1}, 460 \mathrm{~cm}^{-1}$ (Liu et al, 2011). Spektrum adsorben hasil analisa FT-IR dalam penelitian ini dapat dilihat pada gambar 1. 


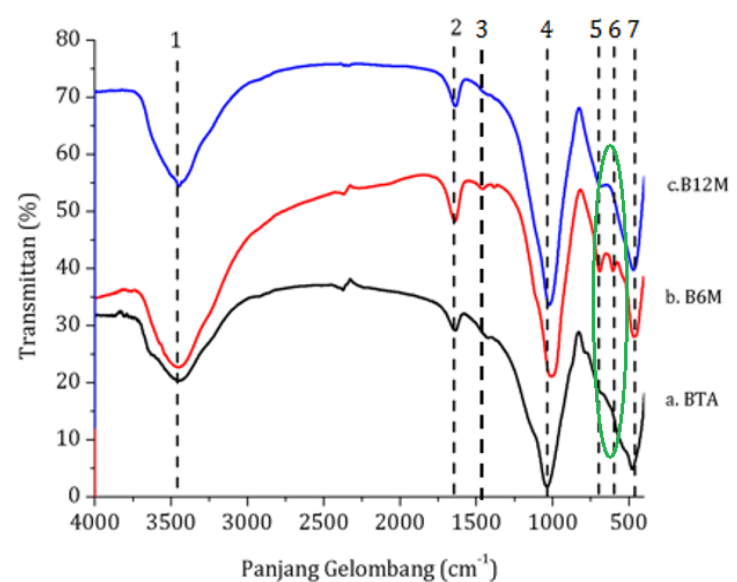

Gambar 1 Hasil analisa bentonit menggunakan FT-IR

Spektrum hasil analisa FT-IR pada gambar 1 terlihat gugus-gugus spesifik montmorillonit yaitu $-\mathrm{OH},-\mathrm{OH}_{2},-\mathrm{AlO},-\mathrm{SiO}$, SiOAl, -SiOSi, dengan panjang gelombang berturut-turut yaitu 3448 - 3450,23 $\mathrm{cm}^{-1}$; 1635,26 - 1640,23 cm-1 $1495,5 \mathrm{~cm}^{-1}$; 1009,31-1036,98 $\mathrm{cm}^{-1}$ dan 692,5 $\mathrm{cm}^{-1}$; $604,08 \mathrm{~cm}^{-1} ; 466,71-477,59 \mathrm{~cm}^{-1}$. Daerah serapan 400-1200 $\mathrm{cm}^{-1}$ disebut sebagai daerah sidik jari. Puncak serapan yang muncul pada daerah sidik jari antara lain 1009,31 - 1036,98 $\mathrm{cm}^{-1} ; 692,5 \mathrm{~cm}^{-1} ; 604,08$ $\mathrm{cm}^{-1} ; \quad 466,71-477,59 \mathrm{~cm}^{-1}$. Berdasarkan gambar 3.1 pada bentonit tanpa aktivasi terdapat bilangan gelombang $3448 \mathrm{~cm}^{-1}$ menunjukkan adanya vibrasi ulur gugus $\mathrm{OH}$ yang terhidrasi molekul air yang teradsorpsi. Hal ini diperkuat dengan adanya pita serapan pada bilangan 1635,26 $\mathrm{cm}^{-1}$ yang menunjukkan adanya vibrasi tekuk dari $\mathrm{H}-\mathrm{O}$ $\mathrm{H}$ dari air yang teradsorpsi didalam bentonit. Adanya pita serapan yang tajam dengan intensitas yang tinggi pada bilangan 1036,98 $\mathrm{cm}^{-1}$ menunjukkan karakteristik dari vibrasi ulur asimetris Si-O. Vibrasi tekuk Si-O-Si ditunjukkan pada bilangan gelombang 477,59 $\mathrm{cm}^{-1}$ (Liu zhirong et al., 2011., Frederico et al, 2010, Sulistyowati dkk, 2018). Dari hasil spektra IR pada gambar 1 terlihat bahwa aktivasi menggunakan $\mathrm{KOH}$ tidak mengubah karakteristik gugus fungsional bentonit. Pada bentonit teraktivasi gugus fungsional khas bentonit masih tetap dipertahankan yaitu $\mathrm{Si}-\mathrm{O}$ dan $\mathrm{Si}$ O-Si yang teramati pada bilangan gelombang 1009,31 - 1020,63 $\mathrm{cm}^{-1}$ dan 466,71 - 472,01 $\mathrm{cm}^{-1}$. Sedangkan dari gambar 1 dapat dilihat terdapat perubahan nilai bilangan gelombang pada spektra bentonit tanpa aktivasi dan teraktivasi $\mathrm{KOH}$. Masing-masing mempunyai puncak yang hampir sama, hanya saja ada beberapa puncak yang mengalami pergeseran bilangan gelombang.

\section{Hasil Analisa XRD pada Bentonit}

Analisis mendasar mengenai struktur dan kristalinitas material bentonit dapat dipelajari melalui karakterisasi menggunakan XRD (X-ray diffraction) merk Bruker D2 Phaset $2^{\text {nd }}$ Gen. Data gambar 2 dibawah ini menampilkan data kristalinitas bentonit tanpa aktivasi(a), bentonit teraktivasi $\mathrm{KOH} \quad 6 \mathrm{M}(\mathrm{b})$ dan bentonit teraktivasi KOH $12 \mathrm{M}(\mathrm{c})$.

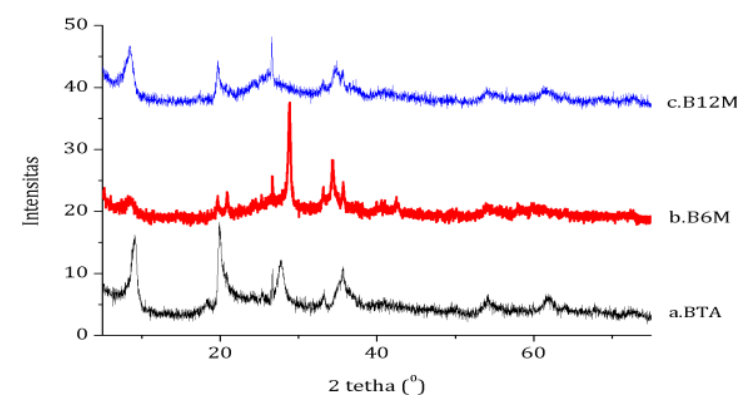

Gambar 2 Hasil analisa XRD BTA, BTK 6M , BTK $12 \mathrm{M}$

Berdasarkan gambar 2 difaktogram bentonit tanpa aktivasi(a) menunjukkan puncak dengan intensitas tinggi pada $2 \theta=9,119^{\circ} \quad\left(d_{\mathrm{hll}}=9,689 \AA\right), \quad 2 \theta=20,483^{\circ}$ $\left(\mathrm{d}_{\mathrm{hkl}}=4,332 \quad \AA\right.$ ). Difaktogram bentonit teraktivasi $\mathrm{KOH} 6 \mathrm{M}$ (b) terdapat pada puncak $2 \theta=19,674^{\circ}\left(\mathrm{d}_{\mathrm{hkl}}=4,508 \AA\right)$ dan difaktogram bentonit teraktivasi $\mathrm{KOH}$ $12 \mathrm{M}(\mathrm{c})$ terdapat pada puncak $2 \theta=7,116^{\circ}$ $\left(\mathrm{d}_{\mathrm{hkl}}=12,326 \AA\right), 2 \theta=19,731^{\circ}\left(\mathrm{d}_{\mathrm{hkl}}=4,495 \AA\right)$. Puncak-puncak tersebut mengindikasikan adanya mineral montmorillonit. Hal ini sesuai dengan ciri khas bentonit, dimana montmorillonit muncul pada puncak $2 \theta=5,78^{\circ}, 2 \theta=17,27,2 \theta=19,9^{\circ}$ dengan basal spacing berturut -turut yaitu 15,3 $\AA, 5,13 \AA$, 4,46 ̊ (S.Chegrouche et al.,1997). Disisi lain muncul puncak intensitas rendah pada $2 \theta=26,671^{\circ} \quad\left(d_{\mathrm{hkl}}=3,339 \AA\right), \quad 2 \theta=49,518^{\circ}$ $\left(d_{h k l}=1,839 \AA\right)$ dan $2 \theta=30,918^{\circ}\left(d_{h k l}=2,889 \AA\right)$ yang mengindikasikan adanya mineral kuarsa dan felspar(Thiry et al., 1983). Berdasarkan data difaktogram yang diperoleh dapat disimpulkan bahwa bentonit 
terdiri dari mineral montorillonit sebagai fasa mineral yang dominan dan mineral lain seperti kuarsa dan felspar.

\section{Hasil Analisa GSA pada Bentonit}

Untuk mengetahui luas permukaan dan porositas bentonit dilakukan analisis menggunakan alat gas sorption analyzer dengan metode perhitungan BET. Hasil analisa gas sorption analyzer dapat dilihat dalam tabel 1 dibawah ini:

Tabel 1. Hasil Analisa GSA Bentonit

\begin{tabular}{|l|c|c|c|}
\hline Karakter & BTA & B6M & B12M \\
\hline LPS $\left(\mathrm{m}^{2} / \mathrm{g}\right)$ & 19,626 & 87,200 & 62,649 \\
\hline VTP $\left(\mathrm{cm}^{3} / \mathrm{g}\right)$ & 0,0392 & 0,1901 & 0,1104 \\
\hline RUP $(\mathrm{nm})$ & 3,9975 & 4,3622 & 3,5261 \\
\hline
\end{tabular}

dengan:

LPS= Luas permukaan spesifik $\left(\mathrm{m}^{2} / \mathrm{g}\right)$

$\mathrm{VTP}=$ Volume total pori $\left(\mathrm{cm}^{3} / \mathrm{g}\right)$

RUP $=$ Rerata ukuran pori (nm)

Berdasarkan tabel 1 dapat dilihat bahwa terjadi peningkatan luas permukaan spesifik pada bentonit. Peningkatan luas permukaan spesifik dan volume total pori pada bentonit teraktivasi basa merupakan akibat interaksi bentonit dengan aktivator yang dapat melepaskan ion $\mathrm{Al}^{3+}, \mathrm{Fe}^{2+}$ dan $\mathrm{Mg}^{2+}$ serta pengotor-pengotor lainnya dari kisi-kisi struktur. Pengotor yang hilang inilah yang menyebabkan volume pori meningkat dan kisi kristal menjadi lebih bersih, jari-jari juga meningkat akibat interaksi dengan aktivator basa(Kurniawan, 2008).

Berdasarkan data luas permukaan spesifik padatan terlihat bahwa perlakuan aktivasi menggunakan $\mathrm{KOH}$ mampu meningkatkan luas permukaan spesifik padatan. Kenaikan luas permukaan spesifik bentonit tanpa aktivasi dari 19,6264 $\mathrm{m}^{2} / \mathrm{g}$ menjadi $87,2001 \mathrm{~m}^{2} / \mathrm{g}$ untuk bentonit teraktivasi $\mathrm{KOH} 6 \mathrm{M}$ dan 62,6497 $\mathrm{m}^{2} / \mathrm{g}$ untuk bentonit teraktivasi $\mathrm{KOH} 12 \mathrm{M}$. Terjadinya peningkatan luas permukaan spesifik bentonit teraktivasi $\mathrm{KOH} 6 \mathrm{M}$ kemungkinan pori-pori bentonit menjadi lebih teratur dan bebas dari pengotor yang ada pada permukaan bentonit, sedangkan penurunan luas permukaan spesifik bentonit teraktivasi $\mathrm{KOH} 12$ disebabkan oleh tingginya konsentrasi aktivator sehingga terjadi kejenuhan larutan yang mengakibatkan tertutupnya pori-pori bentonit.

Tabel 1 menunjukkan rerata ukuran pori pada bentonit tanpa aktivasi dan teraktivasi $\mathrm{KOH}$ relatif sama, hal ini mengindikasikan bahwa tidak terjadi perubahan struktur rangka bentonit. Secara umum ukuran pori bentonit terbagi menjadi 3 yaitu mikropori (<1 nm), mesopori $(2-50$ $\mathrm{nm}$ ), dan makropori (>50 nm) (Unger, 1979). Dari data hasil analisa, dapat disimpulkan bahwa ukuran pori bentonit termasuk dalam kategori mesopori.

\section{Kapasitas Adsorpsi}

Penentuan nilai kapasitas adsorpsi bertujuan untuk mengetahui kemampuan bentonit dalam mengikat ion $\mathrm{Cu}(\mathrm{II})$. Untuk mengetahui nilai kapasitas adsorpsi, peneliti melakukan uji adsorpsi menggunakan metode batch, dimana 1 gram adsorben dicampurkan kedalam larutan ion logam $\mathrm{Cu}(\mathrm{II}) 1000$ ppm $50 \mathrm{ml}$ kemudian diaduk menggunakan magnetik stirrer dengan kecepatan 150 rpm pada suhu $25 \pm 2^{\circ} \mathrm{C}$ selama 60 menit. Berikut nilai kapasitas adsorpsi bentonit disajikan dalam tabel 2 di bawah ini:

Tabel 2 Nilai kapasitas adsorpsi

\begin{tabular}{|l|c|}
\hline Jenis Adsorben & $\begin{array}{c}\text { Nilai Kapasitas } \\
\text { Adsorbsi (mg.g-1) }\end{array}$ \\
\hline BTA & 49,014 \\
\hline BTK 6M & 50,013 \\
\hline BTK 12M & 49,821 \\
\hline
\end{tabular}

Dari data hasil adsorpsi, didapatkan bahwa bentonit yang teraktivasi KOH $6 \mathrm{M}$ mempunyai kapasitas adsorpsi lebih besar dibandingkan bentonit tanpa aktivasi dan terkativasi $\mathrm{KOH} 12 \mathrm{M}$ yaitu 50,013 mg/g. Adanya Proses aktivasi terhadap bentonit menyebabkan kapasitas adsorpsi semakin besar karena proses tersebut telah membersihkan rongga pori bentonit dari molekur air dan oksida logam yang dianggap sebagai pengotor. Rongga-rongga kosong yang terbentuk pada permukaan bentonit dapat memeperbesar permukaan aktif sehingga kemampuan adsorpsi menjadi lebih besar. Hal ini didukung dengan hasil analisa luas permukaan bentonit dimana luas permukaan bentonit teraktivasi $\mathrm{KOH} 6 \mathrm{M}$ 
lebih besar dibandingkan bentonit tanpa aktivasi yaitu $87,2001 \mathrm{~m}^{2} / \mathrm{g}$. Sedangkan pada bentonit tanpa aktivasi luas permukaan spesifik bentonit hanya 19,6264 $\mathrm{m}^{2} / \mathrm{g}$, sehingga meningkatnya luas permukaan pori spesifik akan mengakibatkan kapasitas adsorpsi bentonit teraktivasi semakin tinggi. Namun pada bentonit teraktivasi KOH 12M kapasitas adsorpsi mengalami penurunan dari bentonit teraktivasi $\mathrm{KOH} \mathrm{6M}$ yaitu 49, $821 \mathrm{mg} / \mathrm{g}$. Hal ini disebabkan karena pada konsentrasi yang terlalu tinggi menyebabkan larutan menjadi lewat jenuh dan permukaan gugus aktif bentonit banyak yang tertutupi sehingga kapasitas adsorpsinya menurun. Hal ini dibuktikan dengan hasil FT-IR dan XRD pada penelitian ini, dimana pada bentonit teraktivasi $\mathrm{KOH} 12 \mathrm{M}$ pita serapan pada bilangan gelombang $692,5 \mathrm{~cm}^{-1}$ dan $604,08 \mathrm{~cm}^{-1}$ tidak muncul vibrasi Si-0 dan SiO-Al. Sedangkan pada analisa XRD bentonit teraktivasi $\mathrm{KOH} 12 \mathrm{M}$ terjadi penurunan.

\section{Penentuan Waktu Optimum dan Kinetika Adsorpsi}

Dari hasil nilai kapasitas adsorpsi dan hasil karakterisasi antara bentonit tanpa aktivasi, bentonit teraktivasi $\mathrm{KOH} 6 \mathrm{M}$ dan bentonit teraktivasi $\mathrm{KOH} 12 \mathrm{M}$. Didapatkan bahwa bentonit teraktivasi $\mathrm{KOH} \quad 6 \mathrm{M}$ mempunyai nilai kapasitas adsorpsi lebih besar daripada jenis adsorben lain. Sehingga adsoben ini digunakan untuk menentukan waktu optimum interaksi dengan adsorbat yang ditentukan melalui metode batch. Dimana 1 gram bentonit teraktivasi $\mathrm{KOH} 6 \mathrm{M}$ dicampuran kedalam $50 \mathrm{ml}$ larutan ion logam $\mathrm{Cu}(\mathrm{II}) \quad 1000$ ppm. Diaduk menggunakan magnetic stirer dengan suhu $25 \pm 2{ }^{\circ} \mathrm{C}$. Tujuan pengadukan ini agar larutan menjadi homogen secara sempurna. Untuk mengetahui waktu kontak optimum adsorben, maka dalam penelitian ini dilakukan variasi waktu interaksi yaitu 15 , $30,45,60,75,90,105,120,135,150,165$, dan 180 menit. Hasil dari interaksi ini kemudian dianalisa menggunakan AAS sehingga didapatkan grafik hubungan antara waktu kontak dengan konsentrasi akhir larutan ion $\mathrm{Cu}(\mathrm{II})$ yang teradsorp. Hasil analisa dapat dilihat pada gambar 3 dibawah ini:

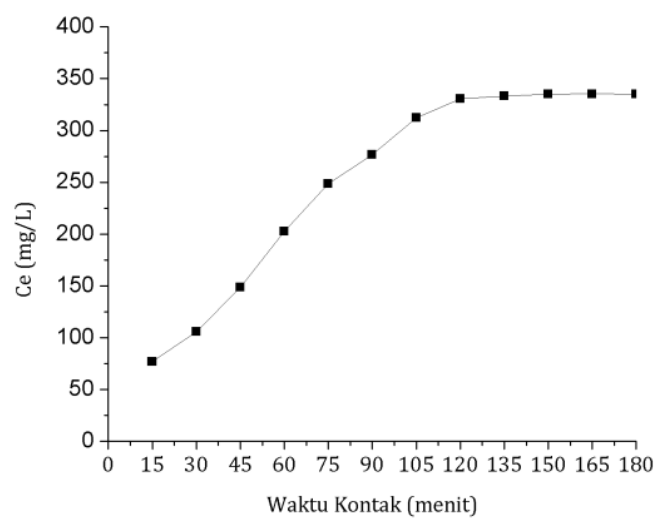

Gambar 3 Grafik waktu kontak vs konsentrasi akhir larutan $\mathrm{Cu}(\mathrm{II})$

Dari grafik dapat dilihat pada menit ke 15 dan 30 menit, jumlah ion $\mathrm{Cu}(\mathrm{II})$ yang teradsorpsi sedikit karena waktu interaksi antara ion $\mathrm{Cu}(\mathrm{II})$ dengan situs aktif pada adsorben relatif kecil. Tetapi menit ke 120 180 jumlah ion logam $\mathrm{Cu}(\mathrm{II})$ yang teradorpsi relatif konstan karena telah terjadi kesetimbangan.

\section{Kinetika Adsorpsi}

Kajian kinetika adsorpsi bertujuan untuk mengetahui laju adsorpsi yang terjadi pada bentonit teraktivasi terhadap logam $\mathrm{Cu}(\mathrm{II})$. Pengujian laju reaksi dalam penelitian ini diawali dengan penentuan orde reaksi. Untuk mengetahui orde rekasi hasil penelitian ini, maka peneliti melakukan uji coba 2 jenis orde reaksi yaitu pseudo orde satu dan pseudo orde dua.

\section{Kinetika pseudo orde satu}

Persamaan kinetika yang digunakan dalam mencari nilai orde reaksi satu semu yaitu $\ln \left(\mathrm{q}_{\mathrm{e}}-\mathrm{q}_{\mathrm{t}}\right)=\ln \mathrm{q}_{\mathrm{e}}-\mathrm{k}_{1} \mathrm{t}$. Dengan $\mathrm{q}_{\mathrm{e}}$ dan $\mathrm{q}_{\mathrm{t}}$ berturut-turut adalah jumlah adsorbat yang teradsorpsi (mg.g-1) pada keadaan kesetimbangan dan pada saat $t$ (menit/jam/detik) dan $\mathrm{k}_{1}$ adalah konstanta adsorpsi orde satu semu. Hasil kinetika pseudo orde satu pada variasi waktu kontak dilakukan dengan membuat grafik $\ln \left(\mathrm{q}_{\mathrm{e}}-\mathrm{q}_{\mathrm{t}}\right)$ vs waktu kontak. Dimana $\ln \left(\mathrm{q}_{\mathrm{e}}-\mathrm{q}_{\mathrm{t}}\right)$ sebagai fungsi y dan nilai $x$ sebagai variasi waktu kontak sehingga hubungan kedua variabel 
ini akan menghasilkan regresi linier seperti gambar 4 di bawah ini:

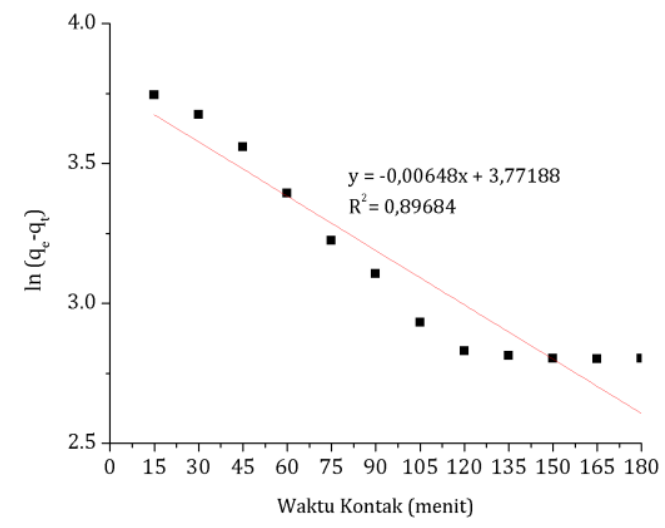

Gambar 4 Grafik kurva kinetika pseudo orde satu pada adsorpsi bentonit teraktivasi KOH 6 M terhadap ion $\mathrm{Cu}^{2+}$

\section{Kinetika Pseudo Orde dua}

Persamaan kinetika yang digunakan dalam mencari nilai orde reaksi satu dua yaitu $\mathrm{t} / \mathrm{q}_{\mathrm{t}}=1 / \mathrm{k}_{2} \mathrm{q}_{\mathrm{e}}{ }^{2}+\mathrm{t} / \mathrm{q}_{\mathrm{e}}$. Dengan $\mathrm{q}_{\mathrm{e}}$ dan $\mathrm{q}_{\mathrm{t}}$ berturut-turut adalah jumlah adsorbat yang teradsorpsi (mg.g-1) pada keadaan kesetimbangan dan pada saat $t$ (menit/jam/detik) dan $\mathrm{k}_{2}$ adalah konstanta laju adsorpsi (g.mg-1.men-1). Hasil kinetika pseudo orde dua pada variasi waktu kontak dilakukan dengan membuat grafik $t / q_{t}$ vs waktu kontak. Dimana $t / q_{t}$ sebagai fungsi y dan nilai $\mathrm{x}$ sebagai variasi waktu kontak sehingga hubungan kedua variabel ini akan menghasilkan regresi linier seperti gambar grafik 5 di bawah ini.

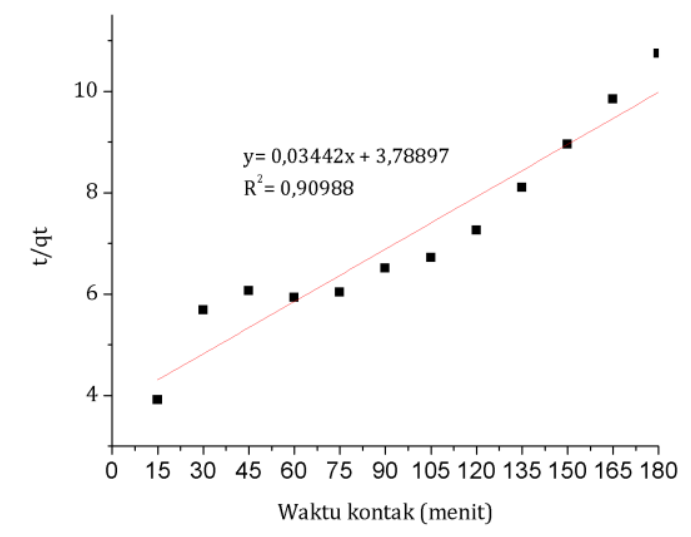

Gambar 5 Grafik kurva kinetika pseudo orde dua pada adsorpsi bentonit terhadap ion $\mathrm{Cu}^{2+}$.
Dari kedua grafik diatas telah dihasilkan koefisien determinasi $\left(\mathrm{R}^{2}\right)$ dan konstanta laju reaksi (k) yang dapat dilihat pada tabel 3 dibawah ini.

Tabel 3. Orde pada variasi waktu kontak

\begin{tabular}{|l|c|c|}
\hline Keterangan & $\begin{array}{c}\text { Pseudo } \\
\text { Orde 1 }\end{array}$ & $\begin{array}{c}\text { Pseudo } \\
\text { Orde 2 }\end{array}$ \\
\hline Nilai R ${ }^{2}$ & 0,8968 & 0,9098 \\
\hline $\begin{array}{l}\text { Konstanta laju } \\
\text { reaksi (k) }\end{array}$ & $6,48 \times 10^{-3}$ & $9,08 \times 10^{-4}$ \\
\hline
\end{tabular}

Dari data yang didapatkan, dapat disimpulkan bahwa adsorpsi bentonit teraktivasi $\mathrm{KOH} 6 \mathrm{M}$ terhadap logam $\mathrm{Cu}(\mathrm{II})$ pada penelitian ini mengikuti model kinetika orde 2 dengan $\mathrm{k}=9,08 \times 10^{-4} \mathrm{~g} \mathrm{mg}^{-1}$ menit-1 dan $\mathrm{R}^{2}=0,90983$.

Berdasarkan data yang diperoleh, proses adsorpsi dalam penelitian ini mengikuti pseudo orde reaksi 2, dimana untuk mencari nilai laju reaksinya menggunakan rumus $\mathrm{v}=\mathrm{k}\left[\mathrm{Cu}^{2+}\right]^{2}$. Karena persamaan laju reaksi didefinisikan dalam bentuk konsentrasi reaktan maka dengan naiknya konsentrasi maka naik pula kecepatan reaksinya, Artinya semakin tinggi konsentrasi, semakin banyak partikelpartikel yang bertumbukan sehingga kecepatan reaksi juga meningkat. Harga konstanta kinetika (k) dapat diperolah melalui hasil kurva waktu kontak vs t/qt.

\section{Simpulan}

Aktivasi $\mathrm{KOH}$ pada bentonit mempengaruhi hasil karakeristik bentonit. Dimana muncul ikatan Si-O-Al dan Si-O-Si pada serapan panjang gelombang $692,5 \mathrm{~cm}^{-1}$ dan $604,08 \mathrm{~cm}^{-1}$ pada analisa FTIR. Kemudian terjadi penurunan intensitas sudut pada difaktogram XRD. Hasil GSA menunjukkan terjadinya peningkatan luas permukaan spesifik akibat proses aktivasi yaitu $19,6264 \mathrm{~m}^{2} / \mathrm{g}$ menjadi $87,2001 \mathrm{~m}^{2} / \mathrm{g}$. Konsentrasi aktivator terbaik pada adsorben bentonit adalah $6 \mathrm{M}$ dengan kapasitas adsorpsi 50,013. Nilai optimum waktu kontak adsorben terhadap ion $\mathrm{Cu}(\mathrm{II})$ adalah 120 menit. Model kinetika adsorpsi ion $\mathrm{Cu}(\mathrm{II})$ oleh bentonit teraktivasi $\mathrm{KOH} 6 \mathrm{M}$ mengikuti proses adsorpsi orde dua semu yang ditandai dengan nilai determinasi 
paling tinggi yaitu 0,9098 dan memiliki $\mathrm{k}_{\mathrm{ads}}$ sebesar $9,08 \times 10^{-4}$ g.mg- $^{-1}$ menit $^{-1}$.

\section{Daftar Pustaka}

Afsin. B., Eren. B., (2007), "An investigation of $\mathrm{Cu}(\mathrm{II})$ adsorption by raw and acid-activated bentonite: A combined potentiometric, thermodynamic, XRD, IR, DTA study", Journal of Hazardous Materials, Vol.151, hal 682-691.

Al-Shahrani, S.S., (2013), "Treatment of wastereater contaminated with cobalt using Saudi activated bentonite", Journal of Alexandria Engineering, Vol.53, hal 205-211.

Araga, Ramya., Soni S., S. Sharma C, (2017), "Fluoride Adsorption from Aqueous Solution using Activated Carbon Obtained from $\mathrm{KOH}$-treated Jamun (Syzygium cumini) Seed", Journal of Environmental Chemical Engineering, 5(6), 5608-5616.

Ariyani. P.A.R., R.P. Eka., R. Fathoni., (2017), “ Pemanfaatan kulit singkong sebagai bahan baku arang aktif dengan variasi konsentrasi $\mathrm{NaOH}$ dan suhu", 6(1): 7-10.

Biyatmoko, D., Hadie, J., Ilham, W., Megasari R., (2012), "Identifikasi keragaman jenis bakteri pada proses pengolahan limbah cair industri minuman dengan lumpur aktif limbah tahu", Universitas Lambung Mangkurat. Vol.8, hal.89-101.

Frederico, G.A., Ana M.X., (2010), "In-situ FTIR analyses of bentonite under high-pressure", Applied Clay Science, 202-208

Ginting, Simparmin Br., Nurfiqah, M.Yassien., (2018), "Sintesis Zeolit A dari Coal Bottom Ash dengan Metode Step Change of Synthesis Temperature dengan Variasi Suhu Kalsinasi Diaplikasikan untuk Dehidrasi Etanol", Universitas Lampung, Vol.9, No.1.
Halada, K., Shimada, M. and Ijima, K., (2008), "Forecasting of the consumption of metals up to 2050", Mater Transac., $49(3), 402-410$.

Kurniawan, D., (2008), "Modifikasi Bentonit menjadi Organoclay dengan Metode Ultrasonik sebagai Absorben PKlorofenol dan Hidroquionon", Skripsi Jurusan Kimia FMIPA.

Li, Jinxiao., Li, Ming., Li, Shijie., Lu, Chunmei., Han, Kuihan., (2018), "Preparation and characterization of super activated carbon produced from gulfweed by $\mathrm{KOH}$ activation". Journal of Electrochemical Science.243, 291-300.

Meilita, T.S., Tuti, S.S., (2003), "Arang Aktif (Pengenalan dan Proses Pembuatannya", Skripsi, Fakultas Teknik, Universitas Sumatera Utara, Medan.

R.Pawar, Randhesyam., Lalhmunsiama, Hari C.B., Seung M.L., (2016), "Activated bentonite as a low-cost adsorbent for the removal of $\mathrm{Cu}(\mathrm{II})$ and $\mathrm{Pb}(\mathrm{II})$ from aqueous solutions: Batch and Column studies", Journal of industrial and engineering chemistry, 213-223.

S.Chegrouche, A.Mellah., S.Telmoune., (1997), "Removal of lanthanum from aqueous solutions by natural bentonite", Elvesier Science. Vol.31. No.7,pp.1733-1737.

Sen Gupta, S., \& Bhattacharayya, K.G., (2008), "Immobilization of $\mathrm{Pb}(\mathrm{II}), \mathrm{Cd}(\mathrm{II}), \mathrm{Ni}$ (II) ions on kalinite and montmorillonite surfaces from aqueous medium", Journal of Environmental Management. 87(1)46-58.

Sulistyowati N., Sriyanti, Adi D., (2018), "Effect of Acid on Natural Zeolite Dealumination on Indigo Carmine Adsorption Capability", Journal of Science and Applied Chemistry. 21(2),102-106. 
Sun, Zengqing., Vollpracht, Anya., (2018). "Isothermal calorimetry and in-situ XRD study of the $\mathrm{NaOH}$ activated fly ash, metakaolin and slag". Cement and Concrete Research.

Sperling, M.V., (2007), "Activated Sludge and Aerobic Biofilm Reaktor", Departement of Sanitary and Enviroment Engineering, Federal University of Minas Gerais, Brazil.

Thirty M., Forette N., and Shimtt J.M. (1983), Tecnique de Difrraction $X$ et Interprettation des Diagrammes, E.N.S.M Paris.

Vellaichanny S., Ventkatiswaran P., Palanivelu K., (2007). "Speciation of heavy metals in electroplating industry sludge and wastewater residue using inductively coupled plasma", Journal of Environmental Science.

Zhirong, Liu., Md.Azhar U., Sun Zhanxue., (2011), "FT-IR and XRD analysis of natural Na-bentonit and $\mathrm{Cu}(\mathrm{II})$ Ioaded Na-Bentonite", Molecular and Biomolecular Spectroscopy, 1013-101 